\title{
Revision of C. G. Thomson's nominal species of Aylacini (Hymenoptera: Cynipidae)
}

\author{
J. L. NIEVES-ALDREY
}

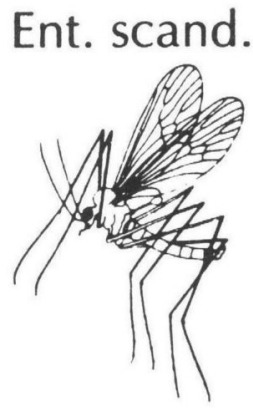

Nieves-Aldrey, J. L.: Revision of C. G. Thomson's nominal species of Aylacini (Hymenoptera: Cynipidae). Ent. scand. 25: 151-158. Copenhagen, Denmark. June 1994. 0013-8711.

\begin{abstract}
The 13 nominal species described by C. G. Thomson in Aulax Hartig (= Aylax Hartig) in 1877 are reviewed and lectotypes designated. Redescriptions are given of four of the six currently valid species. Timaspis luteipes (Thomson) and T. pilicornis (Thomson) are new combinations. The following new synonymies are proposed: Aulax artemisiae Thomson, $A$. crassinervis Thomson and $A$. foveigera Thomson $=$ Aulacidea hieracii (Bouché, 1834); Aulax punctipleuris Thomson = Phanacis centaureae Förster, 1860; Timaspis papaveris Kieffer in Goury \& Gignon, $1905=$ Timaspis luteipes (Thomson); Aulax abbreviatus Thomson and $A$. foveicollis Thomson = Xestophanes potentillae (Retzius in De Geer, 1873); Aulax rugiscuta Thomson = Andricus quercusradicis (Fabricius, 1798).
\end{abstract}

J. L. Nieves-Aldrey, Museo Nacional de Ciencias Naturales (CSIC), José Gutierrez Abascal 2, 28006 Madrid, Spain.

\section{Introduction}

C.G. Thomson was one of the most prominent entomologists of his time (1824-1899). Extremely prolific in his scientific production, his published work numbers over 8,000 pages (Fitton 1982). His fundamental dedication was the study of Hymenoptera. Thomson published more than 2100 new species of Hymenoptera and his collection includes more than 80,000 specimens, most of which were collected by himself, mainly in the south of Sweden. The types of Ichneumonidae described by Thomson were reviewed by Fitton (1982) and types of Chalcidoidea by Hansson (1991). Thomson described species of Cynipidae in the 8th fascicle (1877) of his monumental work 'Opuscula Entomologica'. This paper deals with Thomson's species of aylacine gall wasps, all described in the genus Aulax Hartig, and provides lectotype selections, identifications and some redescriptions. It is preparatory to a paper (Nieves-Aldrey in press) reviewing the genera of Aylacini in W Europe.

The cynipid tribe Aylacini comprises a group of genera and species which form galls on various flowering plants, mainly Asteraceae, Rosaceae, Papaveraceae, Lamiaceae and Valerianaceae, but not on Quercus and Rosa. The original concept of
Aylax Hartig, 1840 [ - Aulax Hartig, 1843 (unjustif. emend.)], as used by Thomson, is very broad and heterogenous. Thomson's first 3 species of $\mathrm{Au}$ lax are inquilines of the tribe Synergini (Ceroptres Hartig and Periclistus Förster); with one exception, the remaining 21 species, of which 13 were newly described by Thomson, belong to the tribe Aylacini.

Most of the examined specimens are in an excellent condition, glued on their side to card points or mounted on micro-pins.

\section{List of species}

Thomson's nominal species described in Aulax are treated below in the original order of appearance in his work. The heading for each species treatment is the currently valid name. For each species is given information on the type material, type locality and identity, lectotypes are designated, and relevant taxonomic and nomenclatural aspects discussed. Species which have not been properly treated in the literature are redescribed.

Timaspis pilicornis (Thomson, 1877) comb. $\mathbf{n}$. (Figs 1-6) 

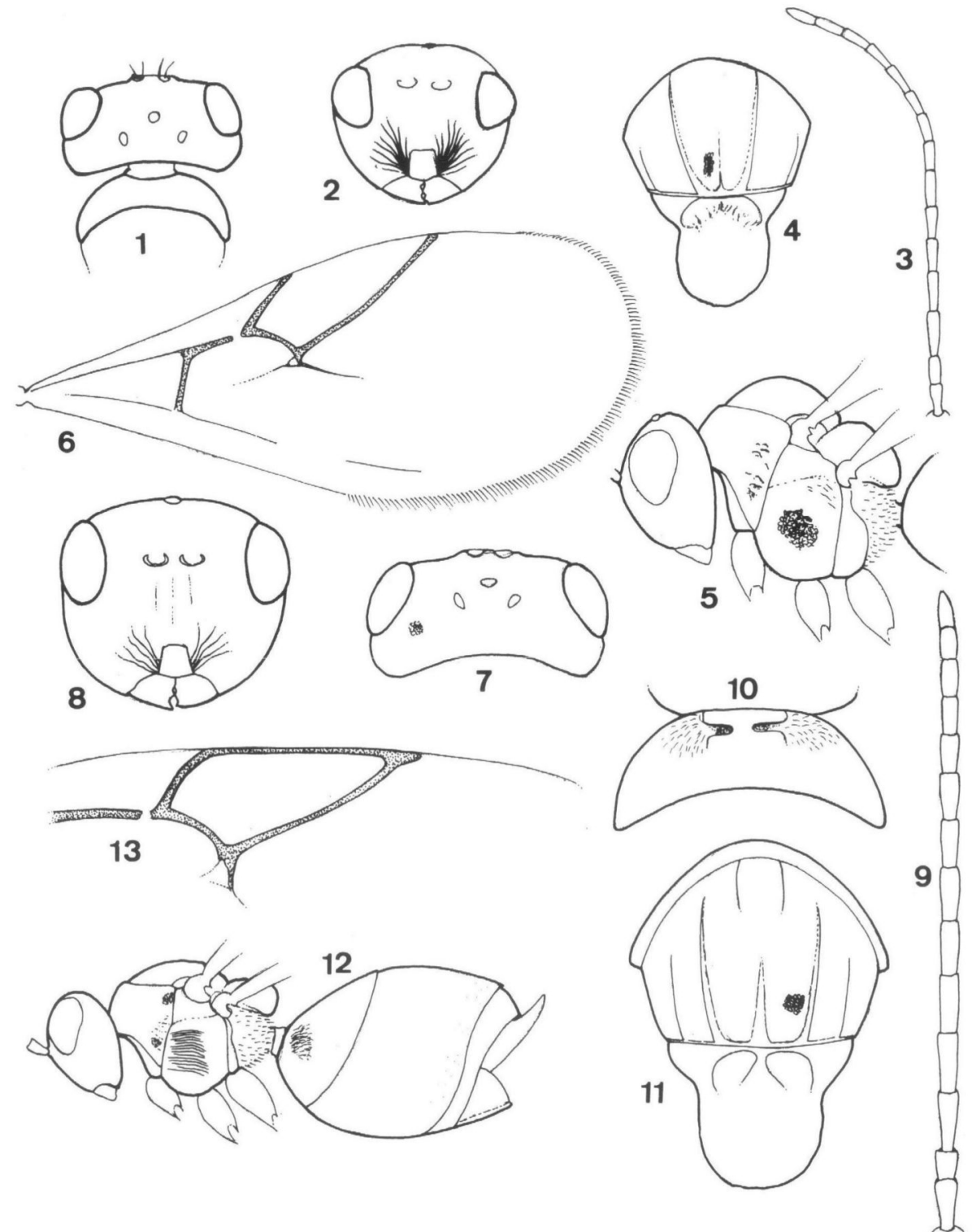

Figs 1-13. (1-6) Timaspis pilicornis (Thomson), $९$ : (1) Head in dorsal view; (2) Head in frontal view; (3) Antenna; (4) Mesoscutum and scutellum; (5) Thorax from left side; (6) Forewing (hairs omitted). (7-13) Aulacidea abdominalis (Thomson), o: (7) Head in dorsal view; (8) Head in frontal view; (9) Antenna; (10) Pronotum; (11) Mesoscutum and scutellum; (12) Body from left side; (13) Radial cell of forewing (hairs omitted).

Aulax pilicornis Thomson, 1877: 801. Type locality: Lund. Aylax pilicornis; Dalla Torre \& Kieffer 1910: 676.

Type material. - Lectotype, $९$, here designated, mounted on card, labeled 'pilicornis' (handwritten). Paralectotypes: 2 \%.

Type locality. - Sweden: Skảne, Lund.

Redescription. - q. Length $2 \mathrm{~mm}$. Mainly brown- 
red; antenna and legs dark yellow ; basal half of gaster light brown, distal half almost black. Wings hyaline; veins brown. Head (Fig. 1), in dorsal view, about two times broader than long. Front and vertex delicately coriaceous; radiating striae of face (Fig. 2) moderately developed, absent medially; clypeus subquadrate; supraclypeal area raised; antenna (Fig. 3) filiform, with 14 antennomeres; A3 about 1.3 times longer than A4. Pronotum (Fig. 1) dorsally only moderately long, without submedial pits; sculpture of pronotum laterally weakly rugose; mesoscutum (Fig. 4) weakly coriaceous-alutaceous; notauli complete ; median groove very weakly impressed in posterior one third of mesoscutum; scutellar foveae narrow, not well defined, confluent; scutellum rugose; mesopleuron (Fig. 5) rugulose-reticulate (Fig. 5), some longitudinal striae visible in upper part. Forewing (Fig. 6) hyaline; radial cell open on margin, about three times longer than broad ; wing fringe moderately long. Gaster without lateral pubescent patch on second tergum; remaining segments smooth, without punctures. Tarsal claws simple.

Comments. - The type specimens are conspecific. Thomson considered this species to be closely related to Aylax minor Hartig, but I consider the morphological features to clearly distinguish it from that species. The lack of submedial pits on pronotum, the rugulose-reticulate sculpture of mesopleuron, together with the lack of a lateral pubescent patch on $\mathrm{T} 2$ of the gaster and the antennal structure assign this species to the genus Timaspis Mayr (sensu Nieves-Aldrey in press), comb. n. It is closely related to, or might even be a senior synonym of Timaspis heraclei (Hedicke, 1923). However, scarcity of material makes it premature to formally establish this synonymy.

\section{Aulacidea abdominalis (Thomson, 1877)}

(Figs 7-13)

Aulax abdominalis Thomson, 1877: 801.

Aulacidea abdominalis; Kieffer 1902: 95.

Type material. - Lectotype, $Q$, here designated, mounted on card, labeled 'abdominalis' (handwritten). Paralectotypes: $4 q$, mounted on micro-pins; $1 \%$, on card.

Type locality. - Sweden.

Redescription. - $Q$. Length: $2.5-3.5 \mathrm{~mm}$. Variable in coloration; head and thorax from pale red-brown to darker or almost black-brown; gaster orange; antenna light brown; legs light brown or yellowish; wing venation brown. Head, viewed dorsally, (Fig. 7) about two times broader than long; viewed frontally, slightly broader than high; front and vertex finely reticulated; radiating striae (Fig. 8) present laterally on the face, incomplete; supraclypeal area with a weak median protuberance; antenna (Fig. 9) with 13 antennomeres; A3 equal in length to A4. Pronotum dorsally long (Fig. 10) with weak reticulate sculpture and some longitudinal striae laterally; submedial pits conspicuous. Mesoscutum (Fig. 11) finely reticulate; notauli faint in anterior one third of mesoscutum; median groove impressed in posterior one half; scutellar foveae ovate, anterior margins almost straight to scutal suture; mesopleuron (Fig. 12) longitudinally striate. Radial cell of forewing (Fig. 13) closed along margin, length about 2.5 times breadth; hair fringe on distal wing margin quite short. Gaster relatively large; longer than head + thorax; second gastral tergum, basally, with a lateral pubescent patch; following segments smooth, with no visible punctures. Tarsal claws simple.

Comments. - The type specimens are conspecific except for card-mounted paralectotype which probably belongs to Aulacidea tragopogonis (Thomson).

This species was included in Dalla Torre $\&$ Kieffer (1910) , but since then has not been recorded. Morphological features place this species in Aulacidea Ashmead, as was proposed by Kieffer (1902). It is closely related to $A$. tragopogonis Thomson, from which it can be differentiated by the following features: general coloration, especially of the gaster; different relative lengths of the third and fourth antennal segments; finely reticulate sculpture of head and mesoscutum; scutellar foveae not arched in the fore edge, and notauli more weakly impressed anteriorly. Biology unknown.

\section{Aulacidea hieracii (Bouché, 1834)}

Aulax artemisiae Thomson, 1877: 802, syn. n. Aulacidea artemisiae; Kieffer 1902: 95.

Type material. - Lectotype, $९$, here designated, mounted on micro-pin, labeled 'artemisiae' (handwritten). Paralectotype: 1 ㅇ.

Type locality. - Sweden: Skåne, Sandhammeren.

Comments. - Thomson attributed the name artemisiae to Saxesen, who collected the conspecific type material, allegedly on Artemisia. The host plant was probably incorrectly identified because 
this material appears identical to Aulacidea hieracii (Bouché, 1834), a gall maker on stems of Hieraci$u m$. Weidner (1968) recorded and redescribed $A$. artemisiae, with mention of the possible gall on $A r$ temisia campestris $\mathrm{L}$., but my examination of Weidner's material revealed that this belongs to Aylax papaveris (Perris, 1839).

\section{Aulacidea hieracii (Bouché, 1834)}

Aulax foveiger Thomson, 1877: 803, syn. $\mathrm{n}$. Aulacidea foveigera; Kieffer 1902: 95.

Type material. - Lectotype, $९$, here designated, labeled 'foveiger' (handwritten). Paralectotypes: 10,4 \&.

Type locality. - Sweden: Skåne, Helsingborg.

Comments. - All specimens of the type series, reared from Hieracium, belong to Aulacidea hieracii (Bouché, 1834).

\section{Aulacidea tragopogonis (Thomson, 1877)}

Aulax tragopoginis [sic] Thomson, 1877: 803.

Aulax tragopogonis (justif. emend.); Dalla Torre 1893: 125.

Aulacidea tragopogonis; Kieffer 1902: 96.

Type material. - Lectotype, $\bigcirc$, here designated, labeled 'tragopogonis' and 'Lund' (handwritten). Paralectotypes: $10^{\circ}, 4$ ㅇ.

Type locality. - Sweden: Skảne, Lund.

Comments. - The conspecific type series was reared from Tragopogon. This well known species (Eady \& Quinlan 1963; Kierych 1971), which makes galls in stems of Tragopogon spp., is distributed all over Europe.

\section{Aulacidea hieracii (Bouché, 1834)}

Aulax crassinervis Thomson, 1877: 803, syn. n.

Aulacidea crassinervis; Kieffer 1902: 95.

Type material. - Lectotype, ơ, here designated, mounted on micro-pin, labeled 'crassinervis' (handwritten). Paralectotypes: $2 \sigma$ and $1 Q$.

Type locality. - Sweden: Skảne, Lindholmen.

Comments. - I found the conspecific type specimens identical with Aulacidea hieracii (Bouché).

\section{Xestophanes potentillae (Retzius in De Geer, 1773)}

Aulax foveicollis Thomson, 1877: 804, syn. n. Xestophanes foveicollis; Kieffer, 1901: 288.
Type material. - Lectotype, $\$$, here designated, mounted on card above 1 paralectotype, $\$$ and an eurytomid parasitoid card-mounted on same pin; labeled 'foveicollis' and 'Lund' (handwritten). Other paralectotypes: $5 \%$, one labelled 'Potentilla reptans' (handwritten).

Type locality. - Sweden: Lund.

Comments. - In Thomson's work it appears as the first of a group of species making galls on Potentilla (Rosaceae). The type specimens, which were reared from $P$. reptans, are conspecific and identical with Xestophanes potentillae (Retzius in De Geer). Mounted on same pin as the lectotype is an Eurytoma sp. (Eurytomidae), which Thomson identified with E. rufipes Walker.

\section{Xestophanes potentillae (Retzius in De Geer, 1773)}

Aulax abbreviatus Thomson, 1877: 805, syn. n.

Xestophanes abbreviatus; Dalla Torre \& Kieffer 1910: 657.

Type material. - $6 \sigma, 3 \circ$. Lectotype, $\sigma$, here designated, mounted on card, labeled 'abbreviatus' and ' $L d$ ' (handwritten). Paralectotypes: $5 \sigma^{\circ}$ and 3 o.

Type locality. - Sweden: Lund.

Comments. - The type specimens are conspecific and identical with Xestophanes potentillae (Retzius in De Geer). The slight differences observed, already pointed out by Thomson, are within the range of variability of this species.

\section{Xestophanes brevitarsis (Thomson, 1877)}

Aulax brevitarsis Thomson, 1877: 805.

Xestophanes brevitarsis; Mayr 1881: 21.

Type material. Lectotype, $\$$, here designated, mounted on card above $3 \sigma^{\circ}$ and $1 \%$ paralectotypes card-mounted on same pin; labeled 'brevitarsis' (handwritten). Other paralectotypes: $50^{\circ}$ and $4 Q$.

Type locality. - Sweden.

Comments. - A valid species recorded from all parts of Europe (Tavares 1931; Eady \& Quinlan 1963; Nieves-Aldrey 1984).

\section{Andricus quercusradicis (Fabricius, 1798)}

Aulax rugiscuta Thomson, 1877: 806, syn. n. Aulacidea rugiscuta; Kieffer 1902: 96.

Type material. - Lectotype, $\%$, here designated, mounted on card, unlabeled. Paralectotypes: $3 \%$.

Type locality. - [Sweden]. 

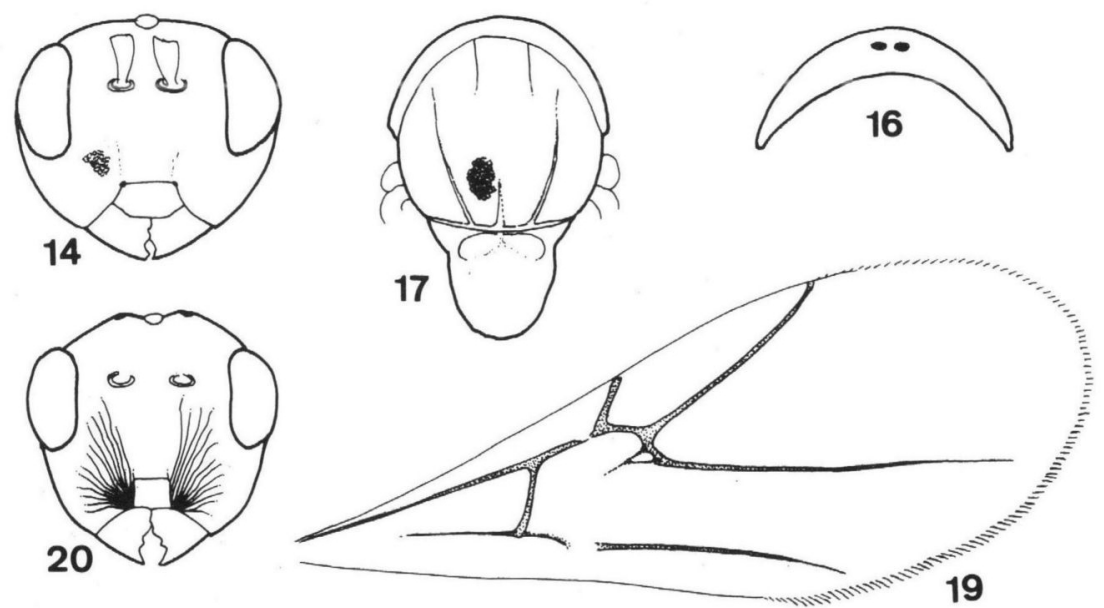

15
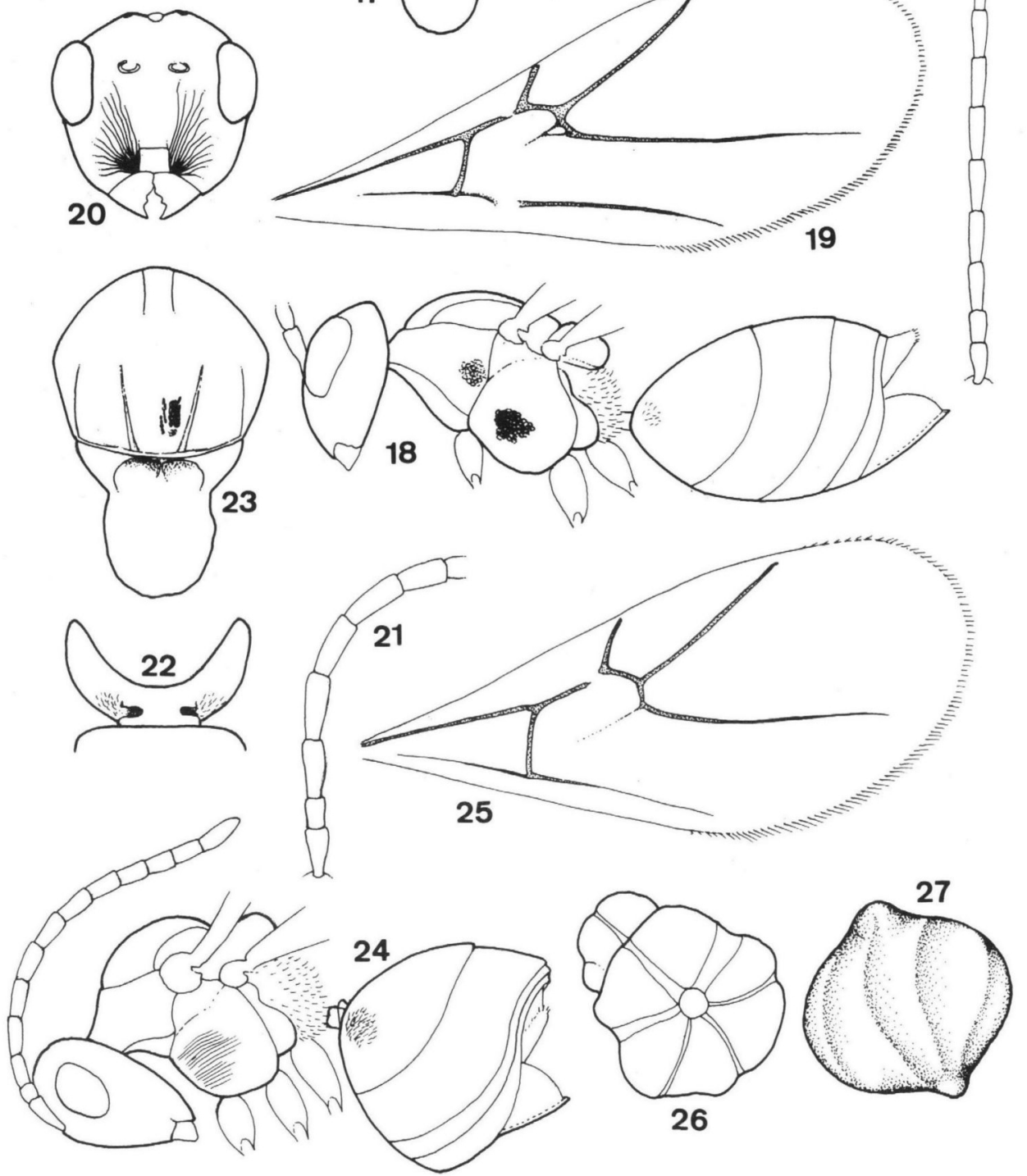

Figs 14-27. (14-19) Timaspis luteipes (Thomson), $Q:$ (14) Head in frontal view; (15) Antenna; (16) Pronotum; (17) Mesoscutum and scutellum; (18) Body from left side; (19) Forewing (hairs omitted); ((20-27) Cecconia valerianellae (Thomson): (20) $\odot$ head in frontal view; (21) First segments of $\sigma^{\circ}$ antenna; (22) $\odot$ pronotum; (23) $\sigma^{\circ}$ mesoscutum and scutellum; (24) $९$ body and antenna from left side; (25) $९$ forewing (hairs omitted); (26) Gall from apical view; (27) Gall from lateral view. 
Comments. - Thomson, in the original description, pointed out that rugiscuta resembles 'Cyn. noduli'. Accordingly, the conspecific type specimens are members of the Cynipini and identical with Andricus quercusradicis (Fabricius) (bisexual generation); Cynips noduli (Hartig) is a synonym.

\section{Timaspis luteipes (Thomson, 1877) comb. $\mathbf{n}$.} (Figs 14-19)

Aulax luteipes Thomson, 1877: 807.

Aylax luteipes; Dalla Torre \& Kieffer 1910: 676.

Timaspis papaveris Kieffer in Goury \& Guignon, 1905: 200 , syn. n.

Type material. - Lectotype, $\odot$, here designated, mounted on card, labeled 'luteipes' (handwritten).

Type locality. - Sweden: Skåne, Örtofta.

Redescription. - $\%$. Length: $2.5 \mathrm{~mm}$. Head and thorax black; gaster red-brown, with posterodorsal part almost black; antenna yellowish and legs entirely yellow-brown. Wing hyaline with yellowish venation. Head, viewed dorsally, slightly less than two times broader than long; viewed frontally slightly broader than high; temples not expanded behind eyes; POL about two times OOL and about 2.5 times greatest diameter of lateral ocellus; front and vertex minutely coriaceous-reticulate ; transfacial line equal to 1.2 times height of eye; face (Fig. 14) with reticulate sculpture, without visible radiating striae; supraclypeal area slightly prominent; clypeus (Fig. 14) trapezoid-shaped, moderately projecting outwards; antenna filiform, with 13 or 14 antennomeres; A3 almost equal in length to A4. Pronotum (Fig. 16) dorsally only moderately long, with reticulate-coriaceous sculpture; submedial pits present; mesoscutum (Fig. 17) reticulate; notauli faint in anterior one third of mesoscutum; median groove present in posterior one third of mesoscutum; scutellar foveae transverse, confluent; scutellum reticulated; mesopleuron (Fig. 18) reticulate. Forewing as long as head + thorax ; radial cell (Fig. 19) open on margin, slightly more than three times longer than broad; hair fringe on distal margin long. Gaster as long as head + thorax; second gastral tergum basally with weak lateral pubescent patch; following segments without punctures.

Comments. - The identity of the lectotype of $l u$ teipes makes Timaspis papaveris Kieffer in Goury \& Guignon a junior synonym. I have seen specimens in the Natural History Museum, London, reared from inconspicuous stem galls on Papaver somniferum, and from Spain, Ribas-Vaciamadrid (new record) which are identical with Thomson's species. A new genus will be proposed for this species elsewhere (Nieves-Aldrey in press).

\section{Phanacis centaureae Förster, 1860}

Aulax punctipleuris Thomson, 1877:807, syn. n. Aulacidea punctipleuris; Kieffer 1902: 96.

Type material. - Lectotype, $\odot$, here designated, mounted on card above $1 \%$ and $1 \sigma^{\circ}$ (in that order) paralectotypes card-mounted on same pin; labeled 'punctipleuris' (handwritten). Other paralectotypes: $10^{\circ}$ and $3 \%$, unlabeled.

Type localities. - Sweden: Skåne, Fogelsång; Öland.

Comments. - The lectotype and 4 paralectotypes of punctipleuris are identical with Phanacis centaureae Förster, while the $\sigma^{\circ}$ and $q$ paralectotypes beneath the lectotype belong to Synergus gallaepomiformis (Boyer de Fonscolombe) and an unidentified species of Figitidae, respectively.

\section{Cecconia valerianellae (Thomson, 1877)}

(Figs 20-27)

Aulax valerianellae Thomson, 1877: 810 .

Cecconia valerianellae; Kieffer 1902: 7 .

Type material. - The type material was previously examined by Weld (1931) and Quinlan (1966). Lectotype, $q$, here designted, mounted on card, on same pin as a gall; labeled 'Weld, 1931' (red, round) and 'Valerianella olitoria' (handwritten). Paralectotypes: $10^{\circ}, 4 \% ; 1$ \% (mouldy) labeled 'scan'; $1 \%$ with separated thorax and gaster and on card rectangle next to two galls labeled 'Valerianella olitoria'; one of the forewings of this specimen is on a slide prepared by Quinlan (examined). Additional material: 4 galls, individually card-mounted.

Type locality. - Sweden: Skåne, Esperöd.

Redescription. - O. Length: $1.7 \mathrm{~mm}$. Red-brown; antenna and legs yellow-brown; wing venation quite pale. Head, viewed dorsally, 1.8 times broader than long; viewed frontally (Fig. 20), as broad as high; front and vertex finely minutely coriaceous; temples not expanded behind eyes; malar space as long as height of eye; POL slightly more than two times OOL; clypeus subquadrate, radiating striae well impressed laterally; supraclypeal area without striae, with a weak median protuberance; transfacial line about three times width of eye; antenna (Fig. 24) with 13 antennomeres; A3 slightly shorter than A4. Pronotum (Fig. 22) dorsally moderately long; with coriaceous-reticulate sculpture and laterally pubescent; submedial pits present broadly 
separated; mesoscutum (Fig. 23) with fine alutaceous sculpture; notauli weakly impressed, absent in anterior half of mesoscutum; median groove absent; scutellar foveae confluent, rounded, not well defined posteriorly; scutellum dorsally quite convex, with reticulate sculpture; mesopleuron (Fig. 24) with fine longitudinal striae. Forewing hyaline; radial cell (Fig. 25) open on margin, about three times longer than broad; wing margins with hair fringe long. Gaster as long as thorax; second gastral tergum with lateral pubescent patch basally; following tergites not punctate.

$\checkmark$. Differs from $\$$ as follows: head, viewed frontally, slightly higher than broad; antenna (Fig. 21) with 14 antennomeres; A4 slightly broadened apically.

The galls (Figs 26, 27) are deformations of the fruits of Valerianella olitoria (Valerianaceae). They are small, irregularly oval or spherical, with meridian lines which begin from the apical area and divide them in 5 or 6 sections.

Comments. - This species has been rarely collected, probably because the galls are small and inconspicuous, difficult to locate. The genus Cecconia Kieffer, which is based on this species, was briefly reviewed by Weld (1952) and Quinlan (1968). The species was recently recorded from the Iberian Peninsula (Nieves-Aldrey 1992).

\section{Taxonomical summary}

\section{AYLACINI}

\section{Aulacidea abdominalis (Thomson, 1877)}

Aulacidea hieracii (Bouché, 1834)

artemisiae Thomson, 1877 (Aulax) syn. n.

crassinervis Thomson, 1877 (Aulax) syn. n.

foveigera Thomson, 1877 (Aulax) syn. n.

Aulacidea tragopogonis (Thomson, 1877)

Cecconia valerianellae (Thomson, 1877)

Phanacis centaureae Förster, 1860

punctipleuris Thomson, 1877 (Aulax) syn. n.

Timaspis luteipes (Thomson, 1877) comb. $\mathbf{n}$. papaveris Kieffer in Goury \& Guignon, 1905 (Timaspis) syn. $\mathbf{n}$.

Timaspis pilicornis (Thomson, 1877) comb. $\mathbf{n}$.
Xestophanes potentillae (Retzius in De Geer, 1773) abbreviatus Thomson, 1877 (Aulax) syn. n. foveicollis Thomson, 1877 (Aulax) syn. n.

Xestophanes brevitarsis (Thomson, 1877)

\section{CYNIPINI}

Andricus quercusradicis (Fabricius, 1798) rugiscuta Thomson, 1877 (Aulax) syn. n.

\section{Acknowledgements}

I am grateful to Roy Danielsson from the University of Lund who kindly put at my disposal all the Thomson types of Aulax on which this work is based. I thank Fredrik Ronquist for critical reading of an early draft of the manuscript. Gary Gibson reviewed and made many improvements of the final manuscript. Financial support was provided by the Research Project 'Fauna Ibérica II', SEUI-DGICYT PB89-0081.

\section{References}

Dalla Torre, K. W. 1893. Cynipidae. Catalogus Hymenopterorum hucusque descriptorum systematicus et synonymicus. $2.140 \mathrm{pp}$. Lipsiae.

Dalla Torre, K. W. \& Kieffer, J. 1910. Cynipidae. Tierreich 24: 1-891.

Eady, R. D. \& Quinlan, J. 1963. Hymenoptera, Cynipoidea. Key to families and subfamilies and Cynipinae (including galls). Handbk Ident. Br. Insects (8)1(a): 1-81.

Fitton, M. G. 1982. A catalogue and reclassification of the Ichneumonidae (Hymenoptera) described by C. G. Thomson. Bull. Br. Mus. nat. Hist. (Ent.) 45: 1-119.

Hansson, C. 1991. Catalogue of the Chalcidoidea (Hymenoptera) described by C. G. Thomson, with a checklist of Swedish species. Ent. scand. Suppl. 38: 1-70.

Hedicke, H. 1923. Beiträge zur Kenntnis der Cynipiden (Hym.) XII. Ein neues Cecidozoon an Heracleum spondylium. Z. Pflkrankh. 33: 81-83.

Kieffer, J. J. 1901. Monographie des Cynipides d'Europe et d'Algerie. 1.687 pp. Paris.

- 1902. Revision du genre Aulax et des genres limitrophes d'Aulax, avec quelques notes sur divers autres Cynipides. Bull. Soc. Hist. nat. Metz, 10: 91-97.

- in Goury, G. \& Guignon, J. 1905. Deux hymenopteres nouveaux. Feuille Nat. 35: 200-202.

Kierych, E. 1971. Galasowki (Hymenoptera, Cynipidae) Bieszczadow wraz $\mathrm{z}$ opisem nowego podgatunku. Fragm. faun. 17: 297-318.

Quinlan, J. 1968. Cynipinae (Hymenoptera) occurring on Phlomis L. Trans. R. ent. Soc. Lond. 120: 275-286.

Mayr, G. 1881. Die genera der gallenbewohnenden Cynipiden. Jber. comm. Oberrealsch. I. Bezirk Wien $20,38 \mathrm{pp}$.

Nieves-Aldrey, J. L. 1984. Notas sobre los Aylaxini de la Península lbérica con descripción de una nueva especie de Isocolus Först. Eos, Madr. 60: 235-250. 
- 1992. Adiciones a la lista de cinipidos ibéricos, especialmente Aylaxini, incluyendo la descripción de una nueva especie de Aulacidea Ashmead (Hymenoptera, Cynipidae). Bolm Soc. port. Ent. Suppl. 3: 493-500.

- In press. Revision of West-European genera of the tribe Aylacini Ashmead (Hymenoptera, Cynipidae). $J$. Hymenopt. Res.

Tavares, J. S. 1931. Cynipidae Peninsulae Ibericae. 2. 131 pp. Ulysippone.

Revised manuscript accepted January 1994.
Thomson, C. G. 1877. XXVIII. Öfversigt af Sveriges Cynips-Arter. Pp. 778-820 in Thomson: Opuscula Entomologica. 3: 778-820.

Weidner, H. 1968. Zur Kenntnis der Gallwespentribus Aulacini (Hymenoptera, Cynipidae). Ent. Z., Frankf.a.M. 10: 105-120.

Weld, L.H. 1952. Cynipoidea (Hym.) 1905-50. 351 pp. Privately printed, Ann Arbor, $\mathrm{MI}$. 